\title{
Violence Prevention and Control at Hospital
}

\author{
Mishra RC ${ }^{1}$ \\ ${ }^{1}$ Facultv of Management. Patan Multidle Cambus (TU). Kathmandu. Nedal
}

\section{INTRODUCTION}

The problem of peace is common to almost all the development on developing countries of the world. More iobs. effective manpower utilization. higher productivitv. higher profits. better working conditions. aualitv education and health facilities will remain mere slogan. if peace does not prevail in the industrv. institutions. hotels and hospitals. A develoding economv cannot afford frequent strikes. lockouts. stopdages of work. violence and hence the importance of peace is even more for such an economv. Permanent peace cannot be achieved unless those within whose hands Dower lies realize that the right cannot be divorced from the duties.

The prevention of workblace violence has emerged as an important safetv issue in and around hospitals and healthcare facilities in Nepal. recentlv. Workblace violence such as phvsical assault or threatening or violent behavior or damaging buildings. infrastructure or claim for compensation is a growing problem in the workplace. According to the 1999 Bureau of labor statistics. the rate of nonfatal assaults on hospital workers is 8.3 assaults Der 10.000 workers which is much higher than the rate of nonfatal assaults for all private-sector industrv. which is 2 per 10.000 workers. ${ }^{1}$ So. even the data shows that the incidence of workblace violence is more in the hoditals than anv other sectors.

\section{THE RISK FACTORS}

Health care and social service workers face an increased risk of work related assaults and violence mav be because of the following reasons: ${ }^{1-3}$

- Dealing with combative. disoriented. uncooperative patients.

- Factors such as the unrestricted movement of the public in the clinics and hospitals and long waits in the emergencv or clinic areas that lead to client frustration over an inabilitv to obtain needed service prombtlv.

- Lack of staff training in recognizing and managing escalating hostile and assaultive behavior.

- Solo work. often in remote locations with no backup or wav to get assistance. such as communication devices or alarm svstems.

- Low staffing levels. high turnover rates and stress.

\section{VIOLENCE PREVENTION PROGRAMS}

A written program for iob safetv and securitv concerning organization's overall safetv and health program offers an effective apbroach for larger organizations. What is needed are clear goals and obiective to prevent workblace violence suitable for the size and comblexitv for the workblace operation. While determining the goals. it should be SMART (where: $S=S$ pecifc. $M=$ Measurable. $\mathrm{A}=$ Accurate. $\mathrm{R}=$ Realistic and $\mathrm{T}=$ Time-bound). ${ }^{4}$ Emblovee should communicate about prevention programs.

At a minimum. workblace violence prevention programs should: 
- Create and disseminate a clear Dolicv of zero tolerance for workplace violence, verbal and nonverbal threats and related actions. Ensure that managers. supervisors. coworkers. clients, Datients and visitors know about this Dolicv.

- Ensure that no emplovee who reports or experiences workblace violence faces rebrisals.

- Encourage emblovees to prombtlv redort incidents and suggest wav to reduce or eliminate risks. Require records of incidents to assess risk and measure progress.

- Outline a combrehensive Dlan for maintaining securitv in the workblace. This includes establishing a link with law enforcement representatives and others who can help indentifv wav to prevent and mitigate workblace violence.

- Assign responsibilitv and authoritv for the program to individuals or teams with appropriate training and skills. Ensure adeauate resources are available for this effort and that the team or the responsible individuals develop expertise on workplace violence prevention in health care and social services.

- Affirm management commitment to a workersupdortive environment that places as much importance on emplovee safetv and health as on serving the patient or client.

- Set ud a combanv briefing as part of the initial effort to address issues such as preserving safetv. supporting affected emplovees and facilitating recoverv.

\section{ELEMENTS OF AN EFFECTIVE VIOLENCE PREVENTION PROGRAM}

The main combonents of effective safetv and health program also apdlv to the prevention of workblace violence: ${ }^{5-7}$

1. Management commitment and emblovee involvement:

Management commitment. including the endorsement and visible involvement of top management. provides the motivation and resources to deal effectivelv with work place violence. It should include:

- Demonstrating organizational concern for emplovee emotional and phvsical safetv and health.

- Eaual commitment to the safetv and health of workers and batients/clients.

- Allocating appropriate authoritv and resources to all responsible parties.

- Maintaining the svstem of accountabilitv for involved managers. supervisors, and emplovees.

- Establishing a comprehensive program of medical and psvchological counseling and briefing for emblovees witnessing assaults and other violent incidents.

- Supporting and imblementing appropriate recommendation from safetv and health committees.

\section{Emolovee involvement should include:}

- Participating in safetv and health committees that receive reports of violent incidents or securitv problems.

- Make facilities inspections and respond with recommendations for corrective policies.

- Taking part in a continuing education program that covers techniaues to recognize escalating agitation. assaultive behavior or criminal intent and discuss appropriate responses.

- Participating in emblovee comblaint or suggestion procedures covering and safetv and securitv concerns.

2. Hazard prevention and control: Engineering and administrative work place control can effectivelv prevent or control work blace hazards. The selection of anv measure should be based on the hazards identified in the workblace securitv analvsis of each facilitv.

\section{Some options emplovers mav chose to:}

- Use a closed circuit video recording for high risk areas.

- Install and regularlv maintain alarm svstem and other securitv devices. hand-held alarms or noise devices.

- Provide metal detectors at the entrance to detect weapons.

- Provide safe room for emblovees during emergencies.

- Provide comfortable client or patient waiting rooms designed to minimize stress.

- Keep automobile well maintained if thev are used in the field.

- State clearlv about the rules and regulation to clients. patients and emplovees that violence is not 
permitted or tolerated.

- Provide management subport during emergencies. Response prombtlv to all the comblaints.

- Supervise the movement of Dsvchiatric clients and patients throughout the facilitv.

- Establish link with local police. redort all incidents clearlv.

- Transfer assaultive clients to acute care units. criminal units or other more restrictive settings.

- Ensure that nurses or phvsicians are not alone when performing intimate phvsical examination of patients.

- Advise staff to exercise extra care in elevators. stairwells and unfamiliar residences: leave the premises immediatelv if there is a hazardous situation: or request police escort if needed.

- Provide staff with identification badges, preferablv without last names. to readilv verifv emblovment.

3. Safetv and health training:

The training should cover following todics:

- The workplace violence prevention policv.

- Risk factors that cause or contribute to assaults.

- Wavs to prevent or diffuse volatile situations or aggressive behavior. manage anger.

- Wavs to deal with hostile people other than patients and clients. such as relatives and visitors.

- Wavs to protect one self and coworkers. including use of the close associates.
- Policies and procedures for reporting and record keeping.

So. all the hospitals need to bring some strong policv so as to make the hospitals violence free place. Even the doctors should maintain their professional ethics and their top most priorities should be proper patient care. Both doctor and patient should understand each other positivelv. Hence. the management should review program effectiveness. and re-evaluate policies and procedures according to the changed circumstances as well as keep the best knowledge of new trends to reduce the workblace violence and such increasing incidence have made policv maker to consider to improve patient-phvsician relationship bv enhancing effective communication and besides this government should be prombt to enforce law and order in the countrv bv bringing culprit to the iustice.

\section{REFERENCES}

1. Michael A. A Handbook of Human Resource Manaqement. New Delhi: Aditva Books Pvt. Ltd: 1992.

2. Robbins SP. Organizational Behavior. 11th ed. New Delhi: Prentice Hall of India Pvt. Ltd: 2006.

3. Decenzo DA. Robbins SP. Personnel/Human Resource Manaqement. New Delhi: Prentice Hall of India Pvt. Ltd: 1993.

4. Desseler G. Human Resource Manaøement. New Iersev: Prentice Hall: 1984.

5. Dunlon IT. Industrial Relations Svstems. Boston MA. USA: Harvard Business School Press: 1993.

6. Brewster C. Harris H. editors. International HRM: Contemporarv issues in Europe. London: Routled $\sigma \mathrm{e}: 1999$

7. Carrell MR. Heavrin C. Collective Bargaining and Labour Relations: Cases. Practice and Law. NewYork: MacMilan Publishing Co.: 1991. 